\title{
Direct electroanalytical determination of methylparathion in solution extracted from soil
}

\section{Fábio Ruiz Simões, Renata Alves de Toledo , Jonatas Lino Rodrigues \& Carlos} M. Pedro Vaz

To cite this article: Fábio Ruiz Simões, Renata Alves de Toledo, Jonatas Lino Rodrigues \& Carlos M. Pedro Vaz (2009) Direct electroanalytical determination of methylparathion in solution extracted from soil, International Journal of Environmental and Analytical Chemistry, 89:2, 95-104, DOI: $10.1080 / 03067310802478252$

To link to this article: https://doi.org/10.1080/03067310802478252

册 Published online: 06 Feb 2009.

Submit your article to this journal ¿

山 Article views: 36

Citing articles: 3 View citing articles 


\title{
Direct electroanalytical determination of methylparathion in solution extracted from soil
}

\author{
Fábio Ruiz Simões ${ }^{\mathrm{ab} *}$, Renata Alves de Toledo ${ }^{\mathrm{b}}$, \\ Jonatas Lino Rodrigues ${ }^{\mathrm{ac}}$ and Carlos M. Pedro Vaz \\ ${ }^{a}$ Embrapa Instrumentação Agropecuária, CNPDIA-EMBRAPA, Caixa Postal 741, \\ 13560-970, São Carlos, SP, Brazil; ${ }^{b}$ NANOFAEL-LIEC-DQ-UFSCar, Rodovia \\ Washington Luiz Km 245, Caixa Postal 676, CEP 13565-905, São Carlos, SP, \\ Brazil;; 'Instituto de Química de São Carlos, IQSC-USP, São Carlos, SP, Brazil
}

(Received 5 September 2007; final version received 11 September 2008)

\begin{abstract}
A fast and simple electroanalytical procedure was applied for the determination of methylparathion in a solution extracted from a typical Brazilian soil using square wave voltammetry and a glassy carbon electrode. The effects of $\mathrm{pH}$, scan rate and surface poisoning were studied in order to establish the optimum conditions for the electroanalysis of methylparathion. It was observed that the substances commonly presented in the soil solution modify the voltammograms, which improves the current values and displaces the peak potential to a less negative value. This was attributed to the more alkaline $\mathrm{pH}$ caused by dissolved organic matter, mineral colloids and other substances in the soil solution. The best response was obtained in neutral or in slightly acidic solutions. In such conditions, the limits of detection were $0.32 \mathrm{mg} \mathrm{L}^{-1}\left(1.21 \times 10^{-6} \mathrm{~mol} \mathrm{~L}^{-1}\right)$ in pure water and $0.36 \mathrm{mg} \mathrm{L}^{-1}\left(1.37 \times 10^{-6} \mathrm{~mol} \mathrm{~L}^{-1}\right)$ in the soil extracted solution.
\end{abstract}

Keywords: methylparathion; square wave voltammetry; glassy carbon electrodes; soil

\section{Introduction}

In Brazil, 300.000 tons of pesticides are applied yearly. Researchers have studied the toxicological characteristics of pesticides [1-4] and their monitoring in the environment [5-7], food [8,9] and medicinal plants [10,11]. However, there is still a great demand for monitoring, training and information about pesticides registration laws [12].

The analysis of pesticides is often accomplished using chromatographic methods. However, electroanalytical procedures present many advantages such as [13]: Rapid measurements (fraction of seconds to minutes); possibility of real time analysis (it is possible to carry out kinetic studies, often complementary with spectrophotometry); determination can be carried out in heterogeneous mixtures that contain biological materials, proteins, surfactants as well as colloidal or slightly soluble particles, without pre-separation steps; possibility to determine oxidised forms in the presence of the reduced ones, and low cost of the equipments and chemicals compared with high-performance liquid chromatography (HPLC), gas chromatography (GC) and atomic absorption spectrometry (AA).

*Corresponding author. Email: fabio@cnpdia.embrapa.br 
The electrochemical behaviour of methylparathion (OO-dimethyl O-(4-nitrophenyl) phosphorothioate) was studied in mercury electrodes [14-16]. The limit of detection (LOD) obtained in neutral aqueous solution using differential pulse polarography (DPP) was around $2 \times 10^{-8} \mathrm{~mol} \mathrm{~L}^{-1}$ (scan rate of $6 \mathrm{mV} \mathrm{s}^{-1}$ and pulse amplitude of $50 \mathrm{mV}$ ). The measurement of methylparathion in the presence of its hydrolysis product, p-nitrophenol, was carried out using a carbon paste electrode modified with C18. According to the optimised experimental conditions of $\mathrm{pH} 6.0$, scan rate of $40 \mathrm{mV} \mathrm{s}^{-1}$ and a pre-accumulation step of $5 \mathrm{~min}$, the LOD reached was $8 \mu \mathrm{g} \mathrm{L}^{-1}$ [17]. Recently, a boron doped diamond (BDD) electrode was used as an anode for the electrochemical combustion of parathion in spiked, pure and natural waters, by using the square wave voltammetry technique (SWV). The results showed that the application in natural waters was improved due to the very low adsorption characteristics of BDD, preventing the fouling of electrode surface from organic pollutants. The electrochemical remediation of parathion contamination was carried out in high positive potential $(3.0 \mathrm{~V})$ and led the electrochemical combustion of parathion to $\mathrm{CO}_{2}$ and $\mathrm{H}_{2} \mathrm{O}$, as measured by the decrease of total organic carbon in the electrolyte [18].

Bare glassy carbon electrodes are mostly used for oxidative measurements of pesticides as shown in Table 1, but it has also been very useful for the electroreduction of nitrocompounds pesticides due to the easy reduction of nitro group within the negative potential range $[19,20]$.

Table 1 shows a short review of electroanalytical procedures developed for the determination of pesticides on glassy carbon electrodes [19,21-32]. As it can be seen, most of the determinations were based on the oxidation of the parent product on the electrode surface, whereas some carbamate insecticides could only be determined by electroanalytical methods after their alkaline hydrolysis to a phenolic product, which can be easily oxidised on the glassy carbon electrode. Most common techniques used were differential pulse voltammetry (DPV) and SWV with LOD of $10^{-6}$ to $10^{-7} \mathrm{~mol} \mathrm{~L}^{-1}$, but adsorptive techniques, as adsorptive stripping voltammetry (AdSV), also have been successfully employed with lower LOD (order of $10^{-8} \mathrm{~mol} \mathrm{~L}^{-1}$ ). Relative standard deviations of the pesticides, at a given concentration, were relatively low (RSD around $3 \%$ ) and they varied according to the pesticide and to the procedure of renewal and activation of the electrode surface prior to the analysis.

Modified glassy carbon electrodes have also been employed for pesticides determination $[27,33,34]$. However, bare glassy carbon electrodes, without any kind of modification, has much more simple use, since no special activation is required for the analysis. Therefore, this work presents a simple electroanalytical procedure for the direct measurement of methylparathion in a solution extracted from a typical Brazilian soil using a bare glassy carbon as working electrode.

\section{Experimental}

\subsection{Materials and reagents}

Methylparathion (99\%) was purchased from Bayer of Brazil and a stock solution of $2000 \mathrm{mg} \mathrm{L}^{-1}$ was prepared in ethanol. Samples of lower concentrations of methylparathion were prepared by dilution of the stock solution in ultra pure water from a milli-Q system (Millipore $^{\circledR}$ ) and also in the solution extracted from a typical Brazilian soil. Other chemicals used were of analytical grade (PA) from Merck. The supporting electrolyte was 


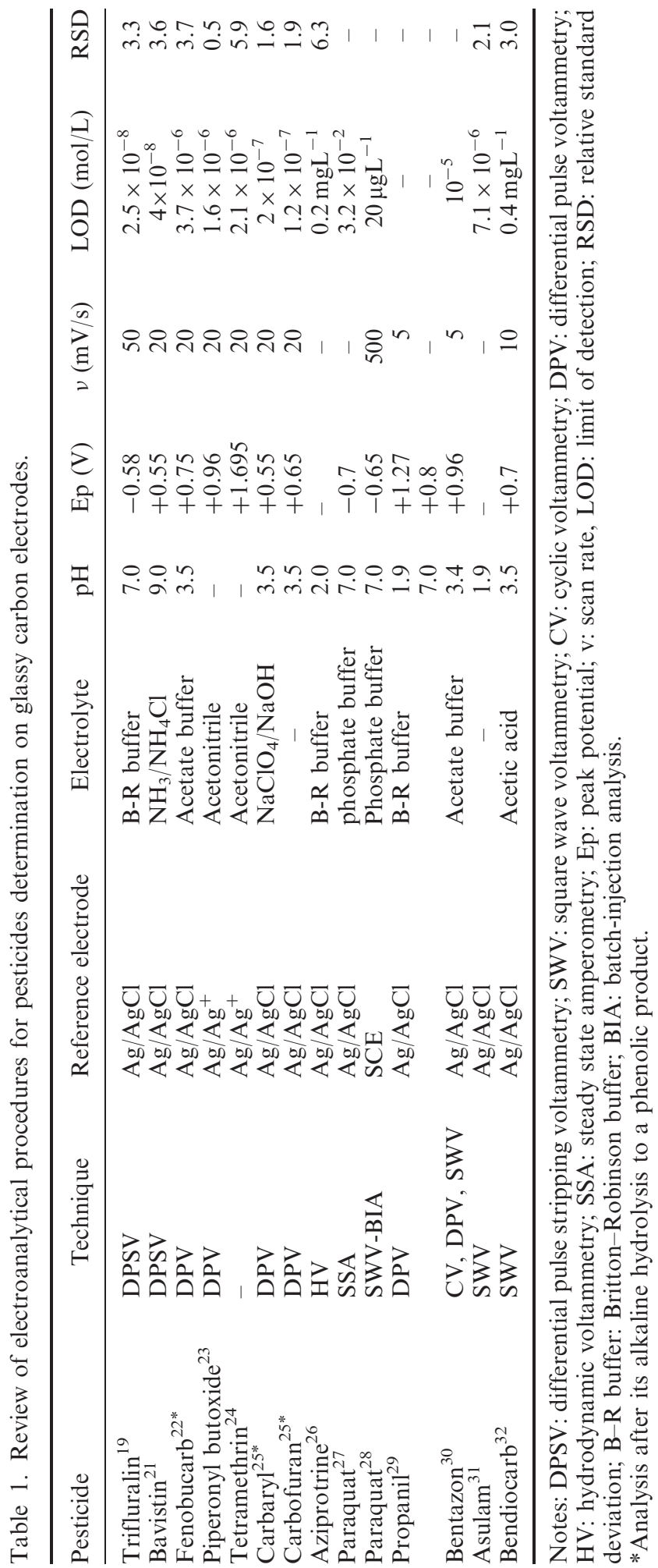


calcium chloride $0.01 \mathrm{~mol} \mathrm{~L}^{-1}$. Stock solutions of $\mathrm{NaOH}$ and $\mathrm{HCl} 1.0 \mathrm{~mol} \mathrm{~L}^{-1}$ were prepared in order to allow the adjustment of the $\mathrm{pH}$ by the dropwise addition of the solutions to avoid significant dilution effect of the samples.

\subsection{Apparatus and procedure}

The soil water extraction system (Figure 1) is composed of a porous ceramic cup, connected to a short pipe covered with a piece of nylon with two orifices, which are connected to two plastic hoses. To promote the flow of the solution from the soil into the porous cup, vacuum was applied during $10 \mathrm{~min}$, with an electric pump connected to one of the hoses. After this period, the pump hose was closed with a Mohr clamp, waiting for 10 min until the soil solution flows to the porous cup. Then, the Mohr clamp was taken off, letting the air enter the system. Finally, the solution was pressed, flowing to the other hose and consequently to the glass tube. The extracted soil solution was stored at low temperature (about $5^{\circ} \mathrm{C}$ ).

All voltammetric measurements were performed with a Potenciostat-Galvanostat AUTOLAB $^{\circledR}$ from ECOCHEMIE model PGSTAT-30, using a working electrode made of glassy carbon (5 mm diameter and $0.5 \mathrm{~mm}$ high) encapsulated with Teflon ${ }^{\circledR}$ bare. The electrical contact was stabilised with a copper wire. A calomel saturated electrode (SCE)

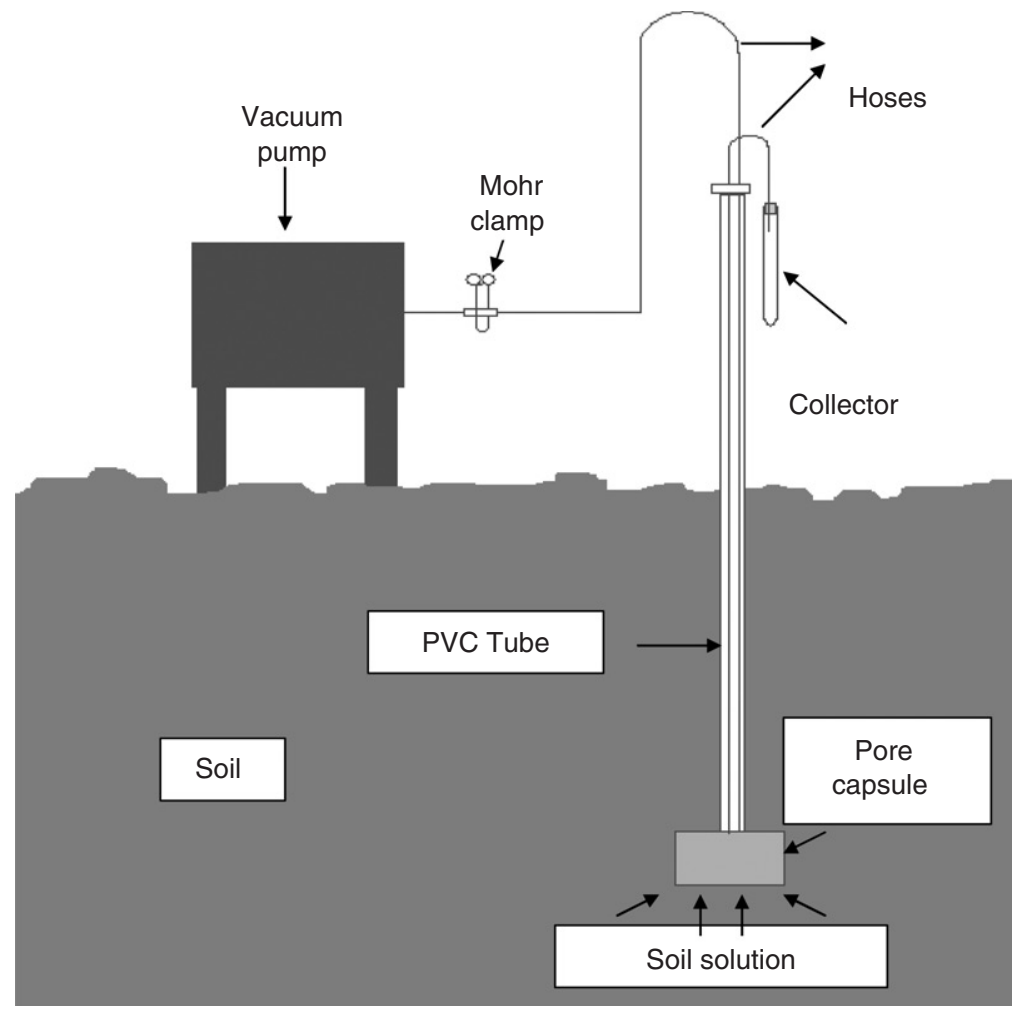

Figure 1. Soil solution extraction system. 
and a platinum electrode $(\mathrm{Pt})$ were used as reference and auxiliary electrodes, respectively. All electrodes were home made.

SWV technique, with a frequency of $50 \mathrm{~Hz}$, increment of $1 \mathrm{mV}$ and pulse amplitude of $50 \mathrm{mV}$, was used to establish an electroanalytical procedure for the analysis of methylparathion. Several electroanalytical aspects were studied as the scan rate, $\mathrm{pH}$ and surface poisoning, in order to obtain the lowest LOD with the glassy carbon electrode. These experiments were done in solutions containing $0.1-40 \mathrm{mg} \mathrm{L}^{-1}$ of methylparathion in $0.01 \mathrm{~mol} \mathrm{~L}^{-1}$ calcium chloride diluted with pure water or with the solution extracted from soil. The samples were deaerated by nitrogen during $15 \mathrm{~min}$ prior to the SWV measurements.

The LOD was determined from the experimental parameters by the equation $3 \sigma / \theta$, where $\sigma$ is the standard mean deviation of 10 voltammograms registered for the blank and $\theta$ is the slope of the analytical curve [35]. The precision of the electroanalytical methodology was checked in different days, in one day $(n=10, n$ referring to the number of measurements, repeatability), and in more than one day $(d=8, d$ referring to the number of the days, reproducibility) for a $2.0 \mathrm{mg} \mathrm{L}^{-1}$ methylparathion solution. To study the accuracy of the proposed methodology, recovery experiments were carried out by adding different concentrations of standard solution of methylparathion in pure electrolyte and also in the soil extracted solution previously spiked with a known amount of the pesticide $\left(1.0 \mathrm{mg} \mathrm{L}^{-1}\right)$.

The effect of the electrode surface poisoning was evaluated by the observation of the voltammograms at each pesticide concentration after three time measurements. After each measurement, the electrode surface was lightly polished with a felt polisher and aluminium oxide dispersion $(1.0 \mu \mathrm{m}$ particle size). This kind of treatment was enough to get a reproductive electrode surface.

\section{Results and discussion}

A cyclic voltammogram of methylparathion in calcium chloride $0.01 \mathrm{~mol} \mathrm{~L}^{-1}$ is presented in Figure 2. An irreversible reduction peak was observed at $-0.7 \mathrm{~V}$ and a reversible redox pair at around $-0.23 \mathrm{~V}$. During the first cathodic sweep, only one peak appeared at $-0.7 \mathrm{~V}$ (peak A) and another at $-0.18 \mathrm{~V}$ (peak B) on the anodic sweep. After subsequent cycles, another peak appeared at $-0.27 \mathrm{~V}$ (peak $\mathrm{C}$ ) on the cathodic sweep. The process clearly indicated that peak A is responsible for the formation of peaks B and C. Similar results were obtained for a mercury electrode [34] and a nafion-coated glassy carbon electrode [30] for the insecticide parathion and for the insecticide fenitrothion with mercury electrode [36]. In these studies, peak $A$ was attributed to the reduction of the nitro group $\left(-\mathrm{NO}_{2}\right)$ to a hydroxylamine group $(-\mathrm{NHOH})$ and the redox pair to the oxidation/reduction of the hydroxylamine group to a nitrous group (-NO).

SWV was chosen as the electroanalytical technique due to its higher sensitivity when compared to other voltammetric techniques such as cyclic voltammetry $(\mathrm{CV})$ and DPV.

The influence of the $\mathrm{pH}$ on the voltammetric response of methylparathion is shown in Figure 3, for a $\mathrm{pH}$ range from 2.6 to 6.9. In $\mathrm{pH} 6.9$, a well-defined peak was observed (peak A presented in the cyclic voltammogram - Figure 2), as already discussed. Peak A decreases when there is a $\mathrm{pH}$ decrease. Therefore, neutral or slightly acidic solutions showed the best condition for the electroanalysis of methylparathion on glassy carbon electrodes. Although peak currents observed in very alkaline solutions are similar to the 


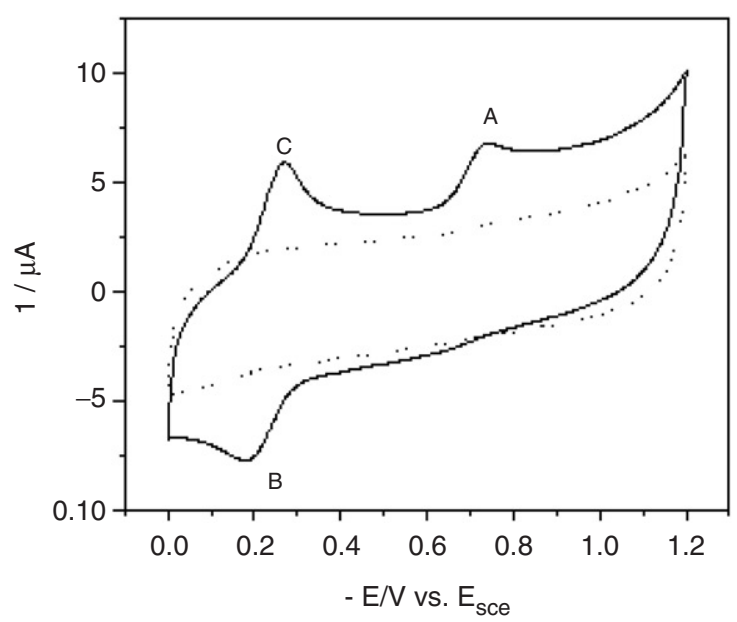

Figure 2. Cyclic voltammograms of calcium chloride $0.01 \mathrm{~mol} \mathrm{~L}^{-1}(\ldots)$ and methylparathion $7.6 \times 10^{-5} \mathrm{~mol} \mathrm{~L}^{-1}, \mathrm{pH} 6.9,100 \mathrm{mV} \mathrm{s}^{-1}\left({ }_{(}\right)$. Initial potential, $E_{i}=0.0 \mathrm{~V}$ and switching potential, $E_{\lambda}=1.2 \mathrm{~V}$.

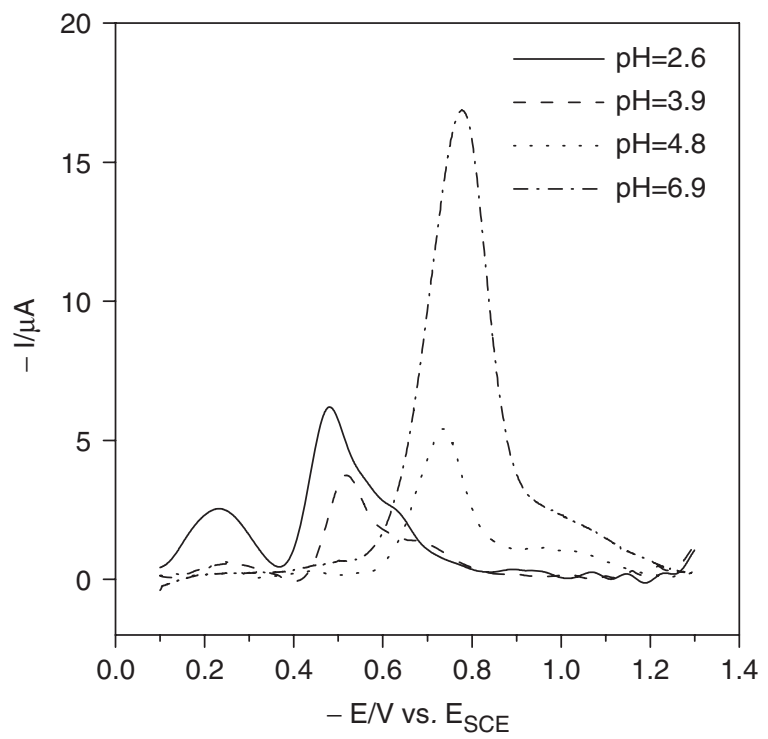

Figure 3. Square wave voltammograms of methylparathion, $3.8 \times 10^{-5} \mathrm{~mol} \mathrm{~L}^{-1}$ (vs. SCE) different $\mathrm{pH}$. Scan rate: $75 \mathrm{mV} \mathrm{s}^{-1}$. Parameters: $50 \mathrm{~Hz}$ frequence, $1 \mathrm{mV}$ increment and $50 \mathrm{mV}$ pulse amplitude.

neutral condition, they are not suitable for analysis due to the rapidly hydrolysis of methylparathion in such medium [15]. The best electroanalytical conditions for methylparathion determination on glassy carbon were obtained using SWV at $50 \mathrm{mV} \mathrm{s}^{-1}$ $(f=50 \mathrm{~Hz}$, scan increment $=1 \mathrm{mV}$ and pulse amplitude $=50 \mathrm{mV}$, data not showed $)$ in neutral or slightly acidic or alkaline solutions ( $\mathrm{pH}$ 6.9), measuring the peak current of peak A $(-0.75 \mathrm{~V})$. 


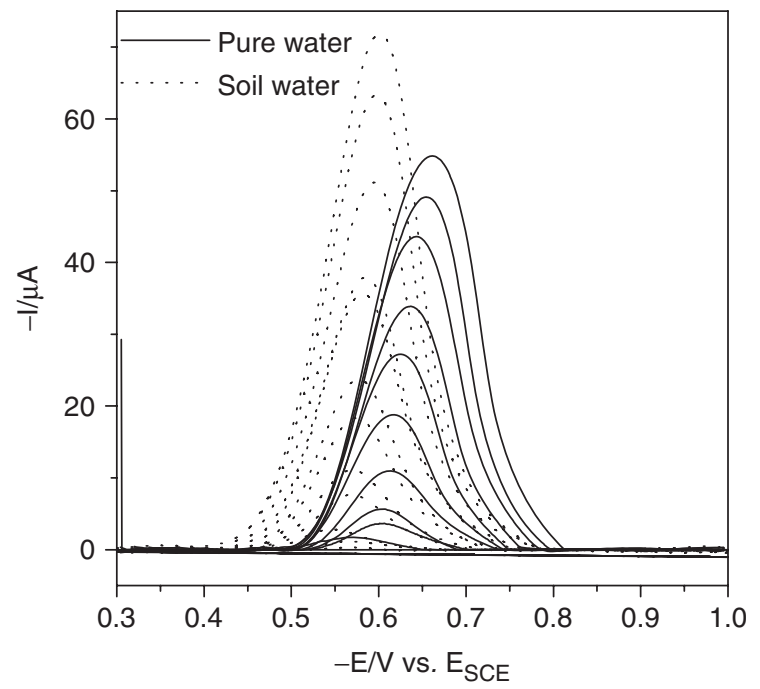

Figure 4. Square wave voltammograms of methylparathion in pure water (solid line) and in soil solution (dot) for different methylparathion concentrations. Calcium chloride $0.01 \mathrm{~mol} \mathrm{~L}^{-1}$, as supporting electrolyte. Parameters: $50 \mathrm{~Hz}$ frequency, $1 \mathrm{mV}$ increment and $50 \mathrm{mV}$ pulse amplitude. $\mathrm{pH} 7.5$ for the soil solution and $\mathrm{pH} 6.9$ for pure water sample. Pesticide concentration interval: $0.1 \mathrm{mg} \mathrm{L}^{-1}$ to $40 \mathrm{mg} \mathrm{L}^{-1}$.

SW voltammograms of methylparathion in such optimal conditions, for different pesticide concentrations, are presented in Figure 4. Establishing a comparison between the voltammograms obtained in pure and in soil solutions, it was observed that the analysis done with the solutions extracted from a Brazilian soil presented a value increase of the reduction peaks and also the displacement of the peak potential to more positive values. There is no significant variation on the $\mathrm{pH}$ measured in comparison with the pure water. According to our previous results [37], substances commonly present in natural samples, like humic substances, can change the electrochemical behaviour of the pesticide, modifying the total (bulk of solution) or local (electrode interface) $\mathrm{pH}$ values. This effect causes the displacement of the peak potentials, favouring the electro-reduction of nitro groups, such as the degradation of the pesticide [37].

Analytical curves of the methylparathion in the soil solution and pure water are presented in Figure 5. As it can be seen, two linear regions are observed, one for concentrations up to about $10 \mathrm{mg} \mathrm{L}^{-1}$ and other for concentrations higher than $10 \mathrm{mg} \mathrm{L}^{-1}$.

According to the results in Figure 5, it was verified that the concentration linearity of the curves is maintained only for concentrations up to 6.0 and $10.0 \mathrm{mg} \mathrm{L}^{-1}$ (pure water soil extracted solution, respectively). This fact was attributed to high concentration values over $10 \mathrm{mg} \mathrm{L}^{-1}$, which can diminish the efficiency of the electroanalysis due to the saturation of the electrode surface. Analysing these regions, the linear regression equations obtained were $I p=\mathrm{A}+\mathrm{B} * \mathrm{C}$, where $I p=1.60+4.51 * \mathrm{C}$ for pure water $\left(R^{2}=0.9920\right)$ and $I p=2.02+4.09 * \mathrm{C}$ for the extracted soil solution $\left(R^{2}=0.9966\right)$.

The sensitivity of the electroanalytical methodology was evaluated by the calculation of the LOD in pure electrolyte and also in extracted soil solution. LOD values obtained were $0.32 \mathrm{mg} \mathrm{L}^{-1}\left(1.21 \times 10^{-6} \mathrm{~mol} \mathrm{~L}^{-1}\right)$ for pure water and $0.36 \mathrm{mg} \mathrm{L}^{-1}$ $\left(1.37 \times 10^{-6} \mathrm{~mol} \mathrm{~L}^{-1}\right)$ for the soil solution. Such results show that there is no significant 


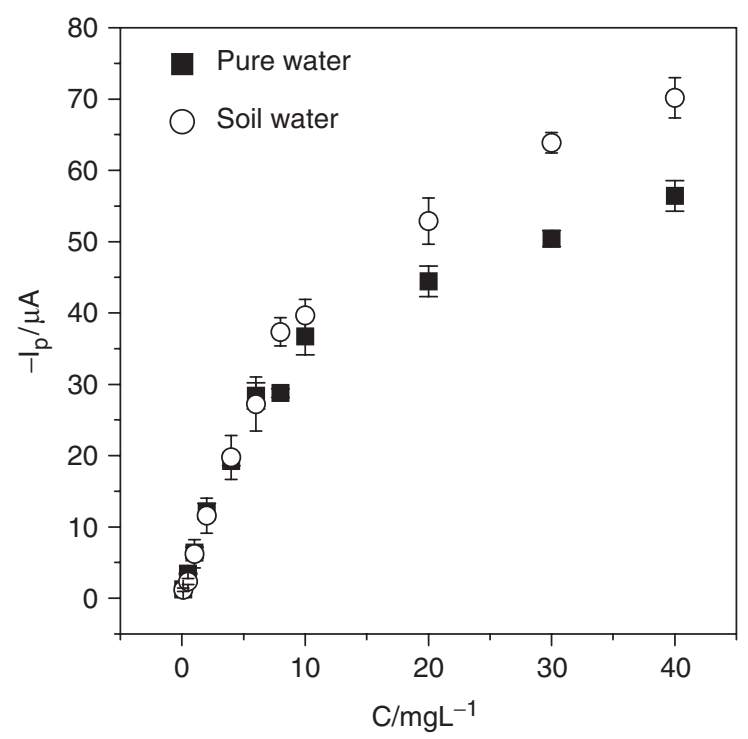

Figure 5. Analytical curves obtained by standard addition of methylparathion in pure water and in a solution extracted from a Brazilian soil. Calcium chloride $0.01 \mathrm{~mol} \mathrm{~L}^{-1}$ as supporting electrolyte. Parameters: $50 \mathrm{~Hz}$ frequency, $1 \mathrm{mV}$ increment and $50 \mathrm{mV}$ pulse amplitude. $\mathrm{pH} 7.5$ for the soil solution and $\mathrm{pH} 6.9$ for pure water sample.

matrix effect of the soil constituents in the electroanalysis of the methylparathion in the soil solution.

It can be observed that the analytical sensitivity of the method decreased softly when comparing the slope of the analytical curve in the supporting electrolyte $\left(4.51 \mu \mathrm{A} \mathrm{mg}^{-1} \mathrm{~L}\right)$ to the one obtained in extracted soil water $\left(4.09 \mu \mathrm{A} \mathrm{mg}^{-1} \mathrm{~L}\right)$. It demonstrates that the matrix constituents of extracted soil water almost do not interfere on methylparathion analysis.

To prove the validation of the method analysis, experiments were done in order to verify the precision (repeatability and reproducibility) of the electroanalytical methodology. The precision of the methodology was checked by performing ten successive measurements for a $2.0 \mathrm{mg} \mathrm{L}^{-1}$ methylparathion solution in pure electrolyte. For repeatability, which was calculated from repeated analysis during one day, the relative standard deviation (RSD) was $3.7 \%$. For reproducibility, calculated from repeated analysis in different days, the RSD was $4.6 \%$. The repeatability was also evaluated in extracted soil water with a RSD of $4.3 \%$.

The recoveries of methylparathion in pure electrolyte and in extracted soil solution were carried out by the standard addition method after three repeated experiments (Table 2). The mean recovery was $101 \pm 3.9 \%$ (pure electrolyte) and $101 \pm 5.1 \%$ (extracted soil solution). The accuracy of the method was checked in terms of relative errors (Bias $\%$ ), which describes the deviation from the expected results, by its recovery during spiked experiments. The value of Bias for both situations was $1.0 \%$, which is within acceptable limits.

Analysing the results presented in Table 2, a high percentage of recovery with very low values of relative error $(1.0 \%)$ was observed. Moreover, the recovery results were very similar to pure and extracted soil solution, proving that the method is very reproductive. 
Table 2. Recovery results for an added concentration of methylparathion $\left(1.0 \mathrm{mg} \mathrm{L}^{-1}\right)$ in relation to the linear range of the calibration curve (Figure 5).

\begin{tabular}{lll}
\hline Water source & Pure (distilled) & \multicolumn{1}{c}{ Soil } \\
\hline Concentration added & $1.0 \mathrm{mg} \mathrm{L}^{-1}$ & $1.0 \mathrm{mg} \mathrm{L}^{-1}$ \\
Concentration found (three curve average) & $1.01 \mathrm{mg} \mathrm{L}^{-1}$ & $1.01 \mathrm{mg} \mathrm{L}^{-1}$ \\
Recovery percentage (Curve 1) & $105 \%$ & $106 \%$ \\
Recovery percentage (Curve 2) & $101 \%$ & $94 \%$ \\
Recovery percentage (Curve 3) & $97 \%$ & $103 \%$ \\
Recovery percentage (Average) & $101 \% \pm 3.9 \%$ & $101 \% \pm 5.1 \%$ \\
Bias (relative error)** & $1.0 \%$ & $1.0 \%$ \\
\hline
\end{tabular}

Note: $* *$ Bias $=($ founded value - real value $/$ real value $) \times 100$

\section{Conclusions}

The electroanalysis of pesticides, in general, involves pre-steps or the redox processes catalyzed by enzymes or other electrodes modifications. In this work, we have developed a fast and a simple electroanalytical procedure for the direct determination of the insecticide methylparathion in a solution extracted directly from a typical Brazilian soil, without pre-conditioning, any treatment or filter procedure using a simple electrode made of a bare glassy carbon. The detection limits (using the SWV technique) were: $0.32 \mathrm{mg} \mathrm{L}^{-1}$ $\left(1.21 \times 10^{-6} \mathrm{~mol} \mathrm{~L}^{-1}\right)$ for pure water and $0.36 \mathrm{mg} \mathrm{L}^{-1}\left(1.37 \times 10^{-6} \mathrm{~mol} \mathrm{~L}^{-1}\right)$ for water extracted from soil.

The results showed that glassy carbon electrodes are efficient materials to be used as electrochemical sensors for the direct determination of pesticides in natural samples, with good sensitivity, precision and accuracy.

\section{Acknowledgements}

The authors wish to thank CNPq (Processes 151810/2005-2 and 310750/2006-7), CAPES and EMBRAPA Agricultural Instrumentation for the financial support.

\section{References}

[1] G.A. Antonucci and I.M.D. Colus, Teratogen. Carcinog. Mutag. 20, 265 (2000).

[2] L.P.G. D’Arce and I.M.D. Colus, Teratogen. Carcinog. Mutag. 20, 161 (2000).

[3] V.L. deCastro, M.A. daSilveira, and M.A. Perez, Internat. J. Sustain. Develop. World Ecol. 6, 172 (1999).

[4] G.A.S. Mendonça, J. Eluf-Neto, M.J. Andrada-Serpa, P.A.O. Carmo, H.H.C. Barreto, O.N.K. Inomata, and T.A. Kussumi, Internat. J. Cancer 83, 596 (1999).

[5] V. Laabs, W. Amelung, A.A. Pinto, M. Wantzen, C.J. da-Silva, and W. Zech, J. Environ. Qual. 31, 1636 (2002).

[6] H.F. Filizola, V.L. Ferracini, L.M.A. Sans, M.A.F. Gomes, and C.J.A. Ferreira, Pesq. Agrop. Bras. 37, 659 (2002).

[7] E.F.G.D. Dores and E.M. De-Lamonica-Freire, Quim. Nova 24, 27 (2001).

[8] C.H.P. Ciscato, A.B. Gebara, and H.D. Spinosa, J. Environ. Sci. Health. Part B-Pest. Food Contam. Agric. Wastes 37, 323 (2002).

[9] B.I.A. Kaipper, L.A.S. Madureira, and H.X. Corseuil, J. Braz. Chem. Soc. 12, 514 (2001). 
[10] V.G. Zuin, J.H. Yariwake, and F.M. Lanças, J. Braz. Chem. Soc. 14, 304 (2003).

[11] V.G. Zuin, J.H. Yariwake, and C. Bicchi, J. Chromatogr. A. 985, 159 (2003).

[12] A.V. Waichman, J. Rombke, M.O.A. Ribeiro, and N.C.S. Nina, Environ. Sci. Pollut. Res. 9, 423 (2002).

[13] P. Zuman, Anal. Lett. 33, 163 (2000).

[14] J.Á. Manzanilla-Cano, M.H. Barcelo-Quintal, E.O. Reyes-Salas, and J. Flores-Rodriguez, Internat. J. Environ. Anal. Chem. 80, 115 (2001).

[15] J.A. Manzanilla-Cano, M.H. Barcelo-Quintal, and E.O. Reyes-Salas, Internat. J. Environ. Anal. Chem. 75, 387 (1999).

[16] G.M. Castanho, C.M.P. Vaz, and S.A.S. Machado, J. Braz. Chem. Soc. 14, 594 (2003).

[17] L. Hernandez, P. Hernandez, and J. Vicente, Fresenius J. Anal. Chem. 345, 712 (1993).

[18] V.A. Pedrosa, D. Miwa, S.A.S. Machado, and L.A. Avaca, Electroanalysis 18, 1590 (2006).

[19] A.E. Radi, Internat. J. Environ. Anal. Chem. 76, 61 (2000).

[20] A.E. Radi and F. Belal, J. Electroanal. Chem. 441, 39 (1998).

[21] Y.Z. Piao and G.F. Wang, Chin. Chem. Lett. 9, 747 (1998).

[22] A.G. Cabanillas, T.G. Diaz, F. Salinas, J.M. Ortiz, and J.M. Kauffmann, Electroanalysis 9, 952 (1997).

[23] D.C. Coomber, D.J. Tucker, and A.M. Bond, Anal. Chem. 69, 898 (1997).

[24] D.C. Coomber, D.J. Tucker, and A.M. Bond, Anal. Chem. 68, 1267 (1996).

[25] A. Giuberteau, T. Galeano-Diaz, F. Salinas, and J.M. Ortiz, Anal. Chim. Acta 305, 219 (1995).

[26] A. Zapardiel, E. Bermejo, J.A. Perez, and M. Chicharro, Fresenius J. Anal. Chem. 367, 461 (2000).

[27] A. Navaratne and N. Susantha, Anal. Lett. 33, 1491 (2000).

[28] F.R. Simões, C.M.P. Vaz, and C.M.A. Brett, Anal. Lett. 40, 1800 (2007).

[29] E.M. Garrido, J.L.F.C. Lima, C. Delerue-Matos, F. Borges, A.M.S. Silva, J.A.P. Piedade, and A.M.O. Brett, J. Agric. Food Chem. 51, 876 (2003).

[30] E.M. Garrido, J.L.F.C. Lima, C. Delerue-Matos, and A.M.O. Brett, Talanta 46, 1131 (1998).

[31] H.P.A. Nouws, C. Delerue-Matos, J.L.F.C. Lima, E.M. Garrido, P. Vincke, and N.A. Maes, Internat. J. Environ. Anal. Chem. 82, 69 (2002).

[32] A. Guiberteau, I. Duran-Meras, T. Galeano, T.J.F. Laranjinho, N.M. Mora, M.F. Suarez, and F. Salinas, Mikrochim. Acta 137, 135 (2001).

[33] J.M. Zen, J.J. Jou, and A.S. Kumar, Anal. Chim. Acta 396, 39 (1999).

[34] P. Manisankar, S. Viswanathan, and H.G. Prabu, Internat. J. Environ. Anal. Chem. 82, 331 (2002).

[35] J.C. Miller and J.N. Miller, Statistics for Analytical Chemistry (Ellis Horwood, Chichester, 1988), p. 103.

[36] S.T. Tanimoto, Master thesis, University of São Paulo, 2002.

[37] F.R. Simões, W.T.L. da Silva, M.L. Simões, L. Martin-Neto, and C.M.P. Vaz, Internat. J. Environ. Anal. Chem. 86, 779 (2006). 